\title{
TUBERCULOSIS CONTACT CONTROL IN BRAZIL: A LIBERATURE REVIEW (1984-2004)
}

\author{
Cláudia Eli Gazetta ${ }^{1}$ \\ Maria de Lourdes Sperli Geraldes Santos ${ }^{1}$ \\ Sílvia Helena Figueiredo Vendramini ${ }^{1}$ \\ Nadia Antonia Aparecida Poletti ${ }^{1}$ \\ José Martins Pinto Neto ${ }^{2}$ \\ Tereza Cristina Scatena Villa ${ }^{3}$
}

Gazetta CE, Santos MLSG, Vendramini SHF, Poletti NAA, Pinto Neto JM, Villa TCS. Tuberculosis contact control in Brazil: A liberature review (1984-2004). Rev Latino-am Enfermagem 2008 março-abril; 16(2):306-13.

This study aims to review plans for tuberculosis control through the analysis of measures for tuberculosis contact tracing in Brazil from 1984 to 2004. This article presents a literature review on tuberculosis control published in manuals of the Ministry of Health and the State Department of Health of Sao Paulo, and in Medline and Lilacs databases. There was a gap in the standardization of control measures in the decade from 1984 to 1994. It was concluded that health professionals need to incorporate TB control and prevention actions from the perspective of health surveillance and systematic monitoring.

DESCRIPTORS: tuberculosis; contact tracing; epidemiological surveillance

\section{CONTROL DE CONTACTOS DE PACIENTES CON TUBERCULOSIS EN BRASIL: REVISION DE LA BIBLIOGRAFÍA (1984-2004)}

Este estudio tuvo como objetivo identificar las medidas de control entre los contactos con tuberculosis (TBC), a través del análisis de la evolución de estas medidas en el Brasil, como parte de los planes para el control de la TBC. Artículo de revisión de la bibliografía entre el período de 1984 a 2004, que tuvo como fuentes los manuales de control para la TBC del Ministerio de Salud y de la Secretaria del Estado de São Paulo, así como artículos ubicados en las bases de datos Medline y Lilacs. RESULTADOS: Fue identificada una laguna en las normas para determinar las medidas del control durante la década de 1984 a 1994. Se concluye que existió falta de involucramiento por parte de los profesionales de la salud en las acciones de control y prevención para la TBC, basadas en las perspectivas de vigilancia en salud y monitoreo sistemático.

DESCRIPTORES: tuberculosis; trazado de contacto; vigilancia epidemiológica

\section{CONTROLE DE COMUNICANTES DE TUBERCULOSE NO BRASIL: REVISÃO DE LITERATURA (1984- 2004)}

Este estudo tem como propósito identificar as medidas de controle de comunicantes de tuberculose (TB) no Brasil, inseridos nos planos de controle da TB. Trata-se de artigo de revisão da literatura referente ao período de 1984 a 2004, que tem como fonte os manuais de controle da TB do Ministério da Saúde e da Secretaria de Estado da Saúde de São Paulo, e artigos localizados nas bases de dados Medline e Lilacs. Resultados: identificou-se lacuna na normatização das medidas de controle durante a década de 1984 a 1994. Conclui-se que faltou aos profissionais de saúde incorporar as ações de controle e prevenção de TB na perspectiva da vigilância em saúde e monitoramento sistemático.

DESCRITORES: tuberculose; busca de comunicante; vigilância epidemiológica

${ }^{1}$ PhD, Nursing Faculty, Medical School at São José do Rio Preto, Brazil, e-mail: tite@eerp.usp.br, Isperli@yahoo.com.br, silviavendra@eerp.usp.br, nadiapoletti@terra.com.br; ${ }^{2}$ PhD Nursing Faculty at FEF, e-mail: jpintoneto@terra.com.br; ${ }^{3}$ Full Professor, University of São Paulo at Ribeirão Preto, College of Nursing, WHO Collaborating Centre for Nursing Research Development, Brazil, e-mail: tite@eerp.usp.br 


\section{INTRODUCTION}

Tuberculosis (TB), a millenary disease, remains a relevant public health issue, despite the significant progress achieved in the late $20^{\text {th }}$ century. The advancements in knowledge and technology have not been enough to affect TB morbidity and mortality, especially in developing countries like Brazil ${ }^{(1)}$.

Considering that TB is relevant in term of its transmission mechanism, it requires special care in searching for symptomatic patients. Thus, every alleged case must be examined and, once the diagnose is confirmed, an epidemiologic investigation must be performed and control measures put into practice, according to the norms by the Ministry of Health $(\mathrm{MH})$ and the state Health Secretariat. The epidemiologic investigation has to include the examination of people living with the patient, aimed at finding the source of infection and learning about other cases originating from the index case ${ }^{(2)}$.

The best prevention strategy is to identify and cure positive cases, which is why sputum smears are one of the most relevant epidemiologic indicators. Sputum smears are currently used to express the magnitude of the TB problem and its tendency in a community ${ }^{(3-4)}$.

The source of infection is often an individual with the pulmonary form of the disease, expelling bacilli to the environment according to his or her bacteriologic index (state). It is estimated that, over one year, a single source of infection in a community can infect, on the average, 10 to 15 people (s)he has contact with ${ }^{(3,5)}$.

When a pulmonary TB patient speaks, sneezes and coughs, (s)he sends different sizes of droplets into the air. The heavier droplets land on surfaces, while the lightest drift in the air or evaporate. Wells' droplet nuclei, measuring up to $5 \mu$ and containing one to two bacilli, can reach an individual's bronchioles and alveoli and initiate multiplication ${ }^{(4)}$.

There is a consensus among TB researchers that every time one person coughs, he or she sends 3,500 infectious particles into the environment and that, every time people sneeze, they cast out one million particles ${ }^{(5)}$. A study performed at the Clementino Fraga Filho University Hospital (HUCFF) showed that the risk of TB contamination among employees at the hospital was $8.2 \%$, against a national average of $0.8 \%$. These results evidenced the TB contamination risk health professionals face in their everyday work activities ${ }^{(5)}$.

Some authors believe that contact control is one way of diagnosing TB at an early stage and reducing its dissemination ${ }^{(4-10)}$. However, it is observed that this strategy has not been effectively put into practice. Despite the recommendation by the Tuberculosis Control
Program (TCP), there is no systematic follow up through registries in the information system ${ }^{(8)}$.

In spite of being a serious public health issue in Brazil, few studies look at the assessment of contacts and disease prevention actions among families and the community as part of the health surveillance program $^{(9-11)}$. Thus, this study is justified by the fact that it is based on the need to learn about what authors on TB in Brazil have addressed regarding contacts.

Hence, the purpose of this study was to perform a systematic literature review on studies about "TB patient contact", available in Brazil from 1984 to 2004, identifying the definitions and use of the search terms comunicantes, contatos, contactantes, as well as associated control measures.

\section{METHODOLOGICAL PROCEDURES}

A systematic literature review was performed from 1984 to 2004 about TB contacts, using the following descriptors: tuberculose, busca de comunicantes, contatos, quimioprofilaxia, and controle (tuberculosis, contact tracing, contacts, chemoprevention, and control).

The literature review was performed from January 2003 to February 2004, using the LILACS (Latin-American and Caribbean Health Sciences) and SCIELO BRAZIL (Scientific Electronic Library On Line) databases, in addition to electronic pages of the Ministry of Health and the São Paulo State Health Secretariat.

The material was selected according to the following inclusion criteria:

- National articles associated with the evolution of TB contact tracing in Brazil;

- As to the type, the study included articles, manuals, guides and HM plans, guidelines, and consensus;

- Regarding the publication period, the selected material was released between 1984 and 2004. This period was chosen based on the increase in TB cases and the consequent concern with contact tracing;

- As to the themes, publications were considered if they presented the definition of terms and forms of conducts for tracing TB contacts.

Publications were excluded if they did not address the changes in term definition and forms of conduct for TB contact tracing.

\section{RESULTS}

Sixty-seven publications were found, 13 of which were selected for analysis in this study. There 
were seven TB control manuals, two guides, two guidelines published as articles and designed by the Brazilian Society of Pneumology and Tisiology (BSPT) and two plans, as shown in Table 1.

Table 1 - Type of publication according to title, source and year (1982-2004)

\begin{tabular}{|c|c|c|c|c|}
\hline $\begin{array}{l}\text { Material } \\
\text { Number }\end{array}$ & $\begin{array}{l}\text { Type of } \\
\text { Material }\end{array}$ & Title & Publication Source & Year \\
\hline 1 & Manual & $\begin{array}{l}\text { Manual of noms for } \\
\text { tuberculosis control. }\end{array}$ & Brazil, Ministry of Health & 1984 \\
\hline 2 & Manual & $\begin{array}{l}\text { Tuberculosis Control. A } \\
\text { proposal to integrate } \\
\text { teaching-senvice. }\end{array}$ & Brazil, Ministry of Health & 1987 \\
\hline 3 & Manual & $\begin{array}{l}\text { Procedures for tuberculosis } \\
\text { control activities }\end{array}$ & Brazil, Ministry of Health & 1989 \\
\hline 4 & Manual & $\begin{array}{l}\text { Tuberculosis Control. A } \\
\text { proposal to integrate } \\
\text { teaching-senice. }\end{array}$ & Brazil, Ministry of Health & 1992 \\
\hline 5 & Manual & $\begin{array}{l}\text { Manual of norms for } \\
\text { tuberculosis control. }\end{array}$ & Brazil, Ministry of Health & 1995 \\
\hline 6 & Guidelines & $\begin{array}{l}\text { Brazilian Consensus on } \\
\text { Tuberculosis }\end{array}$ & $\begin{array}{l}\text { The Brazilian Joumal of } \\
\text { Pneumology- SBPT }\end{array}$ & 1997 \\
\hline 7 & Plan & Tuberculosis Control Plan & Brazil, Ministry of Health & 1999 \\
\hline 8 & Plan & $\begin{array}{l}\text { Strategic Plan for } \\
\text { implementing tuberculosis } \\
\text { control in Brazil 2001-2005 }\end{array}$ & Brazil, Ministry of Health & 2000 \\
\hline 9 & Guide & $\begin{array}{l}\text { Epidemiologic surveillance } \\
\text { guide. }\end{array}$ & Brazil, Ministry of Health & 2002 \\
\hline 10 & Guide & $\begin{array}{l}\text { Tuberculosis: epidemiologic } \\
\text { surveillance guide. }\end{array}$ & Brazil, Ministry of Health & 2002 \\
\hline 11 & Manual & $\begin{array}{l}\text { Tuberculosis Control. A } \\
\text { proposal to integrate } \\
\text { teaching-senvice. }\end{array}$ & Brazil, Ministry of Health & 2002 \\
\hline 12 & Manual & $\begin{array}{l}\text { Technical manual for } \\
\text { tuberculosis control. Primary } \\
\text { Care Handbook. }\end{array}$ & Brazil, Ministry of Health & 2002 \\
\hline 13 & Guin & $\begin{array}{l}\text { II Brazilian Consensus on } \\
\text { Tuberculosis }\end{array}$ & $\begin{array}{l}\text { The Brazilian Joumal of } \\
\text { Pneumology- SBPT }\end{array}$ & 2004 \\
\hline
\end{tabular}

Table 1 presents the general characteristics of the reviewed studies: type and publication year, title and source. It is remarkable that the located publications were manuals, guidelines or plans.

Table 2 - Distribution of the material identified from 1984 to 2004, according to the year and TB contact definitions

\begin{tabular}{|c|c|c|}
\hline N. & Year & TB contact definition \\
\hline 1 & 1984 & "All the people, family or not, who live with the TB patient." \\
\hline 2 & 1987 & Maintains the definition of the 1984 manual. \\
\hline 3 & 1989 & $\begin{array}{l}\text { "A person living with the patient at home or any other closed } \\
\text { environment, on a daily basis, for a long period." }\end{array}$ \\
\hline 4 & $1992-3^{\mathrm{a}} \mathrm{ed}$. & Maintains the definition of the 1987 book. \\
\hline 5 & 1995 & All the people, family or not, who live with the TB patient. \\
\hline 6 & 1997 & $\begin{array}{l}\text { A contact is any person living with a patient either intra- } \\
\text { domiciliary or extra-domiciliary. }\end{array}$ \\
\hline 7 & 1999 & Maintains the 1997 definition. \\
\hline 8 & 2000 & Maintains the 1997 definition. \\
\hline 9 & $2002 a$ & $\begin{array}{l}\text { Contacts who live in the same home with infected patients and } \\
\text { adults who live with patients younger than five years. }\end{array}$ \\
\hline 10 & $2002 b$ & $\begin{array}{l}\text { All TB patient contacts, mainly those of positive pulmonary } \\
\text { patients. }\end{array}$ \\
\hline 11 & 2002c & Maintains the 1995 definition. \\
\hline 12 & 2002d & All intra-domiciliary TB patient contacts. \\
\hline 13 & 2004 & Maintains the $2002^{\mathrm{a}}$ definition. \\
\hline
\end{tabular}

Table 3 presents the definitions of comunicantes/contactantes/contato from 1984 to 2004.

It was observed that every material studied used the terms "controle de comunicantes" (contact tracing), "contatos" (contacts), and "contactantes" as synonyms. Furthermore, it was observed that the official documents published by the Ministry of Health used both the expressions "contatos" and "comunicantes"; and these expressions are also used by Brazilian authors.

The I Brazilian Consensus on Tuberculosis, established in 1997, recommends the term "contactante" be used. But in the II Brazilian Consensus on Tuberculosis, established in 2004, the term used in the guidelines was "contato"(12-18).

Table 3 presents the conduct used for tracing TB contacts from 1984 to 2004.

Table 3 - Distribution of productions identified from 1984 to 2004, according to the year and conducts used for TB contact tracing

\begin{tabular}{|c|c|c|}
\hline $\mathbf{N}$. & Year & Conduct for TB contact tracing \\
\hline \multirow[t]{4}{*}{1} & 1984 & Respiratory symptomatic patients - Sputum smear \\
\hline & & $\begin{array}{l}\text { Tuberculin Test (TT) - Not vaccinated with intrademal Bacillus } \\
\text { Calmette- (BCG) and younger than five years. }\end{array}$ \\
\hline & & Radiologic examination in both cases - when possible. \\
\hline & & $\begin{array}{l}\text { Chemoprevention - asymptomatic contacts younger than fiver } \\
\text { years of age, reactive to TT, not vaccinated with BCG, with nomal } \\
\text { chest X-Ray (XR) and no symptoms. }\end{array}$ \\
\hline \multirow[t]{2}{*}{2} & 1987 & Maintains the 1984 manual conduct and adds: \\
\hline & & $\begin{array}{l}\text { Primary chemoprevention: - newborns, tuberculosis patient } \\
\text { contacts. Secondary chemoprevention: - children under five years, } \\
\text { asymptomatic contacts, not vaccinated with BCG, with normal } \\
\text { chest XR and strong or weak reaction to TT. }\end{array}$ \\
\hline 3 & 1989 & Maintains the 1984 and 1987 manual conduct. \\
\hline 4 & $1992-3^{\text {rd }} \mathrm{ec}$ & $\begin{array}{l}\text { Maintains the } 1987 \text { book conduct, and adds HN-positive } \\
\text { subjects - chemoprevention for asymptomatic individuals with TT } \\
\text { above } 5 \mathrm{~mm} \text { of induration. Non-reactive subjects followed with } \\
\text { immunologic laboratory exams as much as possible, with CD4 } \\
\text { under 350/mm3. }\end{array}$ \\
\hline 5 & 1995 & $\begin{array}{l}\text { Maintains the } 1992 \text { book conduct and adds: active contact } \\
\text { tracing, BCG vaccination of health workers who deal with TB and } \\
\text { AIDS, non-reactive to TT. Chemoprevention for individuals with } \\
\text { HN considered as contacts regardless of the TT. }\end{array}$ \\
\hline \multirow[t]{2}{*}{6} & 1997 & $\begin{array}{l}\text { Intra-domiciliary contacts: } 15 \text { years old or less, reactive, } \\
\text { asymptomatic individuals vaccinated with BCG should be } \\
\text { observed; those who were not vaccinated should be subject to TT } \\
\text { and chemoprevention; when non-reactive, a new TT should be } \\
\text { performed after two or three months. BCG vaccination should be } \\
\text { indicated for non-reactive subjects and chemoprevention for } \\
\text { reactive individuals. }\end{array}$ \\
\hline & & $\begin{array}{l}\text { Symptomatic individuals, aged } 15 \text { years or older, should be } \\
\text { evaluated with chest XR exams, TT, and BAAR. If positive, } \\
\text { treatment should follow. Asymptomatic subjects should be kept } \\
\text { under observation. }\end{array}$ \\
\hline 7 & 1999 & $\begin{array}{l}\text { Maintains the } 1997 \text { definition. Implements the active search for } \\
\text { cases, using all forms of contact exams. }\end{array}$ \\
\hline 8 & 2000 & Maintains the 1997 definition. \\
\hline 9 & $2002 a$ & Maintains the 1997 definition. \\
\hline 10 & $2002 b$ & Maintains the 2002a conduct. \\
\hline 11 & $2002 c$ & Maintains the 2002a conduct. \\
\hline 12 & $2002 d$ & Maintains the 2002a conduct. \\
\hline 13 & 2004 & Maintains the $2002 a$ conduct. \\
\hline
\end{tabular}




\section{DISCUSSION}

The term comunicante is defined as the person who maintained contact with patients or bearers of infectious agents, or environments in which they live. The term contactante, on the other hand, refers to any person or animal that has been in contact with the contaminated environment, and have, therefore, had the opportunity of becoming infected ${ }^{(5)}$.

The MH manual of TB control norms, published in 1984, recommended chemoprevention with daily doses of isoniazid at $10 \mathrm{mg} / \mathrm{kg}$ for six months. The procedure was initiated for positive-patient contacts, five years old or younger, reactive to TT (not vaccinated with $B C G$ ), with normal radiologic exams and no clinical symptoms for $\mathrm{TB}^{(12)}$.

In 1987, the Tuberculosis Control manual was published - A proposal to integrate teaching and service, developed through the special collaboration between university professors and TCP technicians. The manual addresses most professionals working in this field ${ }^{(13)}$, and defines comunicantes as "any person, family member or not, living with a tuberculosis patient". This publication maintains the norms established by the $\mathrm{MH}$ manual for contact tracing in 1984.

Regarding primary chemoprevention, it was recommended for newborns who had contact with positive patients and could not be kept away from the domicile for three months. After this period, if the source of infection was negative, TT was performed. If reactive, isoniazid treatment was maintained until completing six months. If non-reactive, the isoniazid was interrupted and BCG vaccine was applied. Secondary chemoprevention was recommended in situations such as cases of children five years old or younger, positive-patient contacts, asymptomatic, not vaccinated with $B C G$, with normal chest $X R$, and poor or strong $\mathrm{TT}$ reaction ${ }^{(13)}$.

In 1989, the $\mathrm{MH}$ published another Manual with Tuberculosis Control Norms, maintaining the 1984 conducts, and comunicantes or contatos were defined as "any person, family members or not, living with the tuberculosis patient" ${ }^{\prime 12-14)}$.

In 1992, the third edition of the manual "Tuberculosis Control(15): a proposal to integrate teaching and service" broadens the concept of comunicante, considering them as "any person living with the index-case (the identified patient) at home or any other closed environment, for a long period, and on a daily basis". The manual recommended the following actions: sputum smear for respiratory symptomatic patients, TT for children five years old or younger not vaccinated with BCG, and radiologic exam whenever the resource was available. Strong, asymptomatic, reactive subjects with normal XR should be subject to chemoprevention with isoniazid for six months. Non-reactive subjects were vaccinated with CG or subject to new TT after 20 days. In case the subject remained non-reactive in the second test, BCG vaccine was recommended.

Children aged five years or younger, vaccinated, with normal XR and asymptomatic should be kept under observation and forwarded in case of any alteration. Symptomatic subjects, whose exams did not suggest any disease in activity, should be systematically reevaluated. The treatment was recommended for symptomatic children and/or with radiologic changes and diagnosed for TB. Subjects older than five years and respiratory symptomatic should be subject to sputum smear; when repeated negative results are obtained, a chest $X R$ was recommended. Asymptomatic individuals should receive guidance and be followed.

Regarding HIV-positive individuals, the 1992 National Tuberculosis Control Program (NTCP) recommended chemoprotection for asymptomatic individuals with $\pi$ greater than $5 \mathrm{~mm}$ of induration, while non-reactive individuals should be followed with laboratory immunological examinations with $\mathrm{CD}-4$ counting $^{(15)}$.

In 1995, the NPTC was subject to a new evaluation. Changes were made in contact tracing procedures, but the second definition presented in the previous manual was maintained ${ }^{(1)}$, used in the singular form and replacing the word "paciente" (patient) with "doente" (ill person). The instruction was that all should attend the health unit for exams. Respiratory symptomatic individuals should be subject to the regular routine. Asymptomatic contacts should be subject to chest XR. For children aged five years or older, the 1992 standards were used. BCG vaccination was recommended for 'health workers who regularly provide service to TB and AIDS patients, non-reactive to $\Pi^{\prime \prime(1)}$.

In 1996, with the publication of the Emergency Plan (EP) for Tuberculosis Control in the 230 priority municipalities, the following conducts were recommended in terms of contacts: "[...] to implement case searches, based on the identification of 
respiratory symptomatic individuals from the spontaneous demand or referred to the unit for consultation; to implement case searches based on bacteriological exam of every respiratory symptomatic individual; to implement case searches based on all forms of exams for TB-case contacts ${ }^{(16)}$.

The I Brazilian Consensus on Tuberculosis ${ }^{(14)}$ replaces the denomination "comunicante" with "contactante", defined as "every person living with a TB patient". Furthermore, they can be classified as intra-domiciliary (people living in the same home of a TB patient), and extra-domiciliary (people who share common environments with a TB patient, which can be leisure, work, or institutional places) ${ }^{(17)}$.

The following criteria were considered priorities in assessing contacts: a) intra-domiciliary symptomatic individuals of pulmonary TB patients; b) aged less than 15 years or more than 60; c) contacts with conditions predisposing to illness (HIV infected, diabetes or any other immunodeficiency); d) institutional extra-domiciliary contacts $^{(17)}$.

A specific conduct was established: to investigate intra-domiciliary contacts aged 15 years or younger, asymptomatic individuals vaccinated with BCG should be observed; those non-vaccinated would be subject to TT and chemoprotection if reactive; if non-reactive, a new $\mathrm{TT}$ was recommended after two or three months. Non-reactive individuals should be vaccinated with BCG, and reactive individuals should follow chemoprotection.

Also in agreement with Consensus I, intradomiciliary subjects aged 15 years or older and symptomatic should be assessed with chest $X R, \Pi$, and BAAR, and treated if positive. Asymptomatic individuals should be kept under observation ${ }^{(17)}$.

In 1998, the NPTC recommended, regarding the search for cases among contacts: to identify the respiratory symptomatic individuals among contacts. The identified respiratory symptomatic individuals should be subject to sputum smears. TB-case contacts should be identified and examined. The respiratory symptomatic individuals with repeatedly negative sputum smear results should be examined with XR and/or sputum culture. Healthy individuals should be protected with BCG vaccination and chemoprotection $^{(16)}$.

In 2002, the MH published research instruments for health professionals, emphasizing the importance of monitoring contacts, as presented below $^{(3-4)}$.
The Tuberculosis Control Manual - a Proposal to Integrate Teaching and Service (2002) maintains the definitions of the 1984 and 1995 manuals $^{(5)}$.

The 2002 Epidemiologic Surveillance Guide ${ }^{(3)}$ recommends that: contact control be performed mainly for contacts living with positive-TB patients, especially intra-domiciliary, and adults living with patients aged five years or younger, in order to identify the infection source. In addition, the assessment of pulmonary TB-case domiciliary contacts with positive sputum smears should follow these recommendations: asymptomatic intra-domiciliary adult contacts, observation and instructions; symptomatic, sputum smears (if negative, observation and instructions, and treat positive cases). Children aged 15 years or less, and not vaccinated, should be subject to TT (if nonreactive, vaccinate with $B C G$, and, if reactive, chest teleradiography should be performed and, if suggestive for TB and with clinical symptoms, should proceed to treatment). Children with normal chest $\mathrm{XR}$ and without clinical symptoms should be forwarded to chemoprotection. Children vaccinated and asymptomatic should only receive instructions. Symptomatic children presenting a vaccination scar should be subject to sputum smear and a chest XR (when suggestive for TB and with clinical symptoms, they should be forwarded for treatment). In cases of normal XR and absence of clinical symptoms, symptomatic medication and follow up should be carried out.

Indications for chemoprotection were maintained for newborns living in an infection focus, and extended to children aged 15 years or younger, not vaccinated with BCG, who had contact with a positive pulmonary-TB case, without TB-disease signs, reactive to $T T$ of $10 \mathrm{~mm}$ or more.

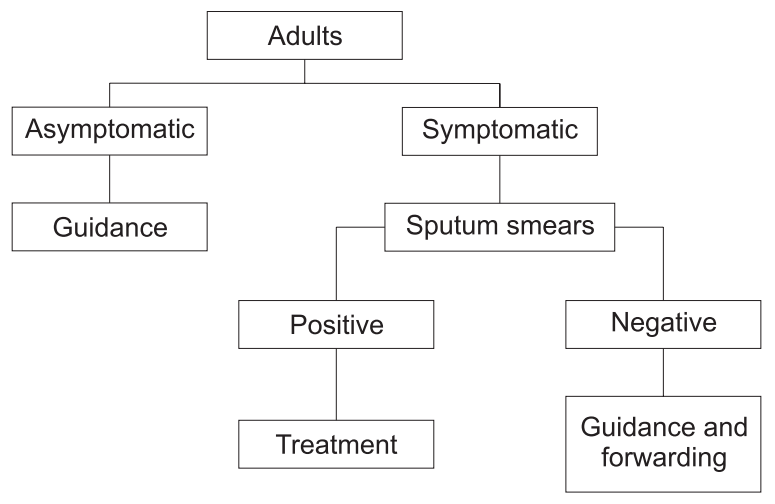

Source: BRASIL, MS, 2002

Figure 1 - Contact control in Brazil - adults 


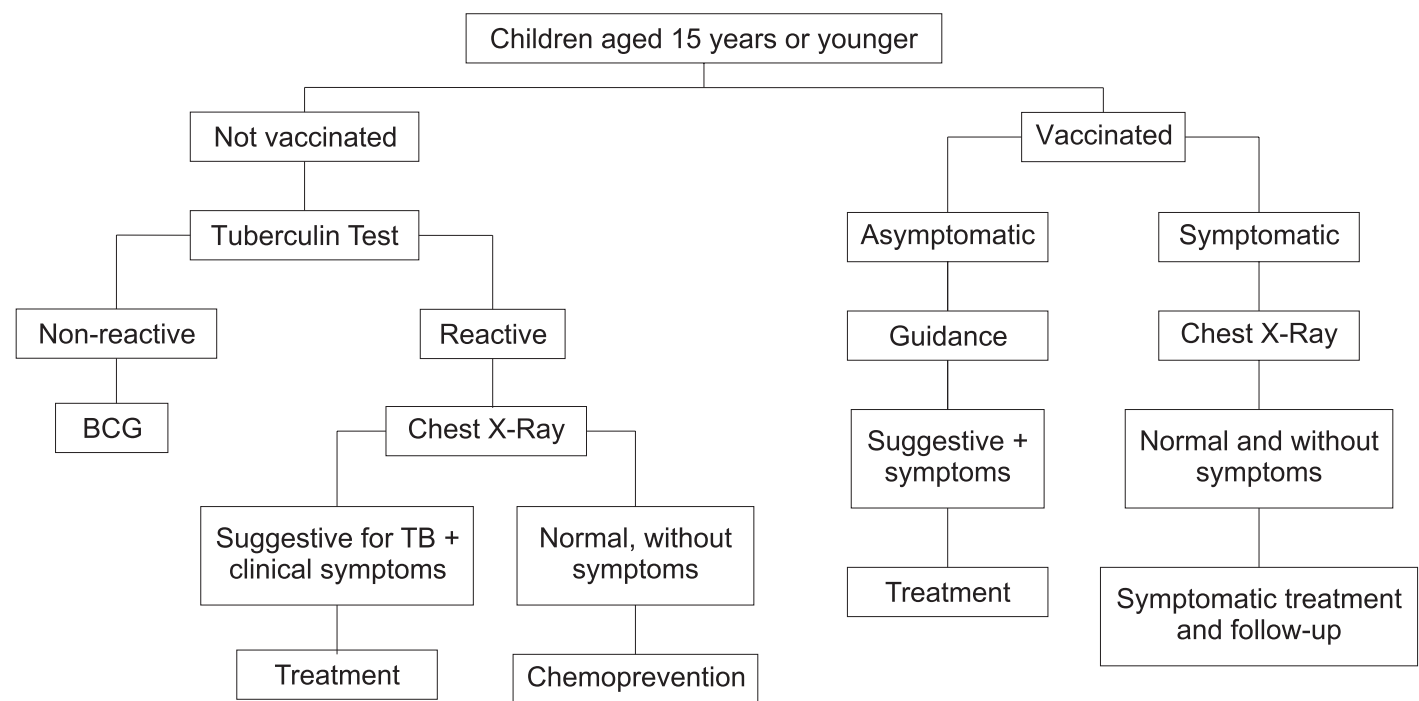

Source: BRASIL, MS, 2002

Figure 2 - Contact control in Brazil - children aged 15 years or younger

The II Brazilian Guidelines on Tuberculosis, designed by BSPT in 2004, recommended the conduct proposal in children, TB patient contacts, which determined that diagnosis should be based on clinical examinations, radiologic results, and $\mathrm{TT}$, regardless of the vaccination scar. The history of contact with a TB patient, positive or not, should be valued mainly for children of school age or younger, due to the time of exposure to the transmission focus $^{(18)}$.

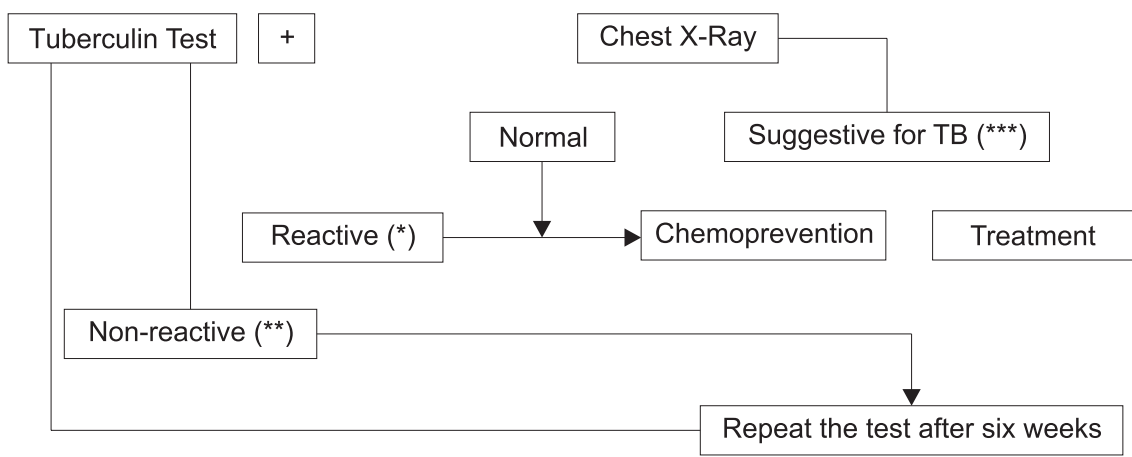

$\left(^{*}\right)$ above $10 \mathrm{~mm}$ in children not vaccinated with BCG or above $15 \mathrm{~mm}$ in children vaccinated with BCG. In the case of a repeated test, the individual may be considered reactive if there is a difference $\geq 10 \mathrm{~mm}$ between the first and second test.

$\left.{ }^{* *}\right)$ inferior induration compared to the reactive test.

$\left({ }^{\star \star *}\right)$ hilar and/or paratracheal adenomegalies, pneumonias with any radiological aspect of slow evolution.

II Brazilian Guidelines on Tuberculosis

Figure 3 - Conduct in TB contact children

In 2004, a new plan is established for the NPTC, which recommends the following actions for TB epidemiologic surveillance: to implement a strategic investigation for an active TB search in emergency hospital services in large urban centers, in groups with greater risks, including indigenous populations, alcoholics, as well as shelter, prison, street populations and people living in risk areas attended by the health units, and also every positive-TB case contact; and intensify contact examination for every TB patient ${ }^{(8)}$. 


\section{CONCLUSION}

Thirteen publications were analyzed in this study, seven of which were TB control manuals, two guides, and two guidelines published as articles and designed by the Brazilian Society of Pneumology and Tisiology (BSPT) and two plans. The analyzed material shows growing concern with contact monitoring in Brazil, and also that health service conducts were only proposed in the late 1990's.

The analysis of this material permitted the conclusion that, over ten years, from 1984 to 1994, there were no changes in concepts and conducts on the standardization of actions for the control of TB patient contacts. The conducts were restricted to the people living within the same environment, focused on the family only.

The marginal position that TB contact surveillance actions occupied as an intervention proposal (conduct) for all health services until the late 1990s was reviewed due to the increase in TB cases in that period, which triggered the expansion in concepts and conduct proposals that integrate prevention actions in a systematic way.

Regarding contact analysis and assessment, it is concluded that both the definition and conducts presented in the $\mathrm{MH}$ manuals and class associations have been broadened.

As from 1994, the expanded communicant concept has supported the control actions because, instead of considering exclusively the people living with the patients, it included all those people with any direct contact with the patient, at home or at work.

\section{REFERENCES}

1. Ministério da Saúde (BR). Coordenação de Pneumologia Sanitária. Manual de normas técnicas para o controle da tuberculose. 4a ed. Brasília (DF): Ministério da Saúde; 1995. 2. Ministério da Saúde (BR). Secretaria de Políticas Públicas. Departamento de Atenção Básica. Coordenação Nacional de Pneumologia Sanitária. Plano estratégico para implementação do plano de controle da tuberculose no Brasil de 2001-2005: resumo executivo. Brasília (DF): Ministério da Saúde; 2000.

3. Ministério da Saúde (BR). Fundação Nacional de Saúde. Tuberculose: guia de vigilância epidemiológica. Brasília (DF): Ministério da Saúde; 2002.

4. Styblo K, Meijer J. Avances recientes en la epidemiologia de la tuberculoses em relacion com la formulacion o readecuacion de los programas de Control. Bol Union Inter Tuberc 1978; 53(4):295-309.
Furthermore, it also included priority groups such as HIV-positive individuals, individuals with respiratory symptoms for over three weeks, people living in institutions and health workers who dealt with TB patients. The understanding about the protective action toward the transmission of the TB bacillus was improved. This conduct includes the use of medications, such as chemoprevention with isoniazid, as well as specific action by the health team involved with active case searching. In 2002, it was proposed that communicants be followed with deadlines and through home visits.

Another important issue that occurred in the late 1990s was the reorganization of the cities' health systems through the decentralization of TCP actions to all health services, thus integrating primary health care services. There was an increase in the incorporation of contact assessment activities, which became normatized in TB control manuals.

These standards are valid until today. However, health service organizations face some operational challenges. There is a lack of systematization of contact assessment activities in terms of monitoring and epidemiologic surveillance actions performed by TCP and primary care teams.

Therefore, readjusting the Communicant Control Form can be an important measure to identify the non-assessed individuals and elaborate service and follow-up protocols for TB communicants. Epidemiologic surveillance and monitoring TB and communicants in an integrated fashion through the information systems (SINAN, EPI- TB, WEB-TB) that do not contemplate contact follow-up.

5. Ministério da Saúde (BR). Secretaria Nacional de Programas Especiais de Saúde. Divisão de Pneumologia Sanitária. Campanha Nacional Contra a Tuberculose. Controle da tuberculose. Uma proposta de integração ensino-serviço. Brasília (DF): Ministério da Saúde; 2002.

6. Kritski AL, Bonfim G, Castelo Filho A, Mello FQ. Reação em cadeia da polimerase LRCP/PCR, aplicada ao diagnóstico de tuberculose. J Pneumol 1997; 23(1):33-42.

7. Ministério da Saúde (BR). Manual técnico para o controle da tuberculose. Brasília (DF): Ministério da Saúde; 2002. Caderno de Atenção Básica n. 6

8. Ministério da Saúde (BR). Secretaria de Vigilância Epidemiológica. Coordenação Geral de Doenças Endêmicas. Programa Nacional de Controle da Tuberculose. Brasília (DF): Ministério da Saúde; 2004.

9. Kritski AL, Marques MJO, Rabahi MF, Vieira MAMS, WerneckBarroso $E$, Carvalho $C E$, et al. Transmission of tuberculosis to close contacts of patients with multidrug- resistant tuberculosis. Am J Resp Crit Care Med 1996 January; (153):331-5. 
10. Villa TCS, Mishima SM, Rocha SMM. Os agentes de enfermagem nas práticas sanitárias paulista: do modelo bacteriológico à programação em saúde (1889-1983). Rev Latino-am Enfermagem 1994 janeiro; 2(2):73-85.

11. Carvalho ACC, Kritski AL, Ruffino-Netto A. Investigação dos contatos de pacientes com tuberculose pulmonar: prioridades e conduta. Pulmão 2002; 11(2):95-101.

12. Ministério da Saúde. Secretaria (BR). Secretaria Nacional de Programas Especiais de Saúde. Divisão Nacional de Pneumologia Sanitária. Programa Nacional de Controle da Tuberculose. Manual de normas para o controle da tuberculose. Brasília (DF): Ministério da Saúde; 1984.

13. Ministério da Saúde (BR). Secretaria Nacional de Programas Especiais de Saúde. Divisão Nacional de Pneumologia Sanitária. Programa Nacional de Controle da Tuberculose. Manual de normas para o controle da tuberculose. Brasília (DF): Ministério da Saúde; 1989.

14. Ministério da Saúde (BR). Secretaria Nacional de Programas Especiais de Saúde. Divisão de Pneumologia Sanitária. Campanha Nacional Contra a Tuberculose. Controle da tuberculose. Uma proposta de integração ensino-serviço. CNCT/NUTES. Brasília (DF): Ministério da Saúde; 1987.

15. Ministério da Saúde (BR). Secretaria Nacional de Programas Especiais de Saúde. Divisão de Pneumologia Sanitária. Campanha Nacional Contra a Tuberculose. Controle da tuberculose. Uma proposta de integração ensino-serviço. CNCT/NUTES. Brasília (DF): Ministério da Saúde; $3^{a}$ ed. 1992.

16. Ministério da Saúde (BR). Fundação Nacional de Saúde. Centro Nacional de Pneumologia Sanitária. Centro Nacional de Epidemiologia. Centro de Referência Hélio Fraga. Plano nacional de controle da tuberculose. Brasília (DF); 1999.

17. Sociedade Brasileira de Pneumologia e Tisiologia. Consenso Brasileiro de Tuberculose. J Pneumol 1997 novembro-dezembro; 23(6):294-345.

18. Sociedade Brasileira de Pneumologia e Tisiologia. II Consenso Brasileiro de Tuberculose: Diretrizes Brasileira para Tuberculose. J Bras Pneumol 2004 Jun; 30 (Supl 1):S1-S86. 